\title{
6th KEITH MILLIS SYMPOSIUM FOCUS SECTION
}

\author{
Thomas Prucha \\ Rochester Hills, MI, USA
}

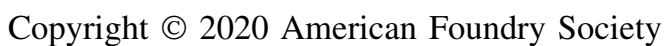

https://doi.org/10.1007/s40962-020-00516-0

Contained in this section are invited papers from the 6th Keith Millis Symposium on Ductile Iron held October 23-26, 2018, at the Sonesta Resort, Hilton Head Island, South Carolina, USA. These papers are published in the IJMC by permission of the Ductile Iron Society (DIS). When Keith Millis first added magnesium to a bath of molten iron back in 1942, he could not have predicted that the incredible reaction that took place would reverberate to this day. Yet it has, because of Keith. While the discovery of ductile iron may have been serendipitous, its successful growth in the marketplace was due almost solely to Keith's efforts to develop the revolutionary new metal for commercial use. Keith supervised the research activities that were necessary to determine and demonstrate ductile iron's superior capabilities. He then spearheaded a promotional campaign to develop new markets, utilizing sales calls, brochures, advertising-even television-to convince foundries to take advantage of ductile iron casting technology.

Thanks to Keith, the world is blessed with better automobiles, more accurate tools and stronger bulldozers. Thanks to Keith, water enters our homes more efficiently. And thanks to Keith, users of ductile iron enjoy a livelihood that otherwise would not have existed.

Therefore, back in 1993, the first ever Keith Millis Symposium was organized and held with then subsequent ones being held every 5 years. The AFS co-sponsored the 2008 and 2013 4th and 5th Symposiums with the IJMC publishing papers from the 5th and now the 6th symposiums. Starting with the 5th symposium, the DIS thought that it was time they paid Keith back and acknowledge their appreciation for the effect his work had on all of our lives. The society decided that all proceeds from the Keith Millis Symposiums would go to the FEF and be invested in the perpetual scholarship in Keith's name. Administered by the Foundry Educational Foundation, the Keith Dwight Millis Scholarship Fund promotes the development of ductile iron through the education of future engineers, metallurgists and foundrymen of the world.
The following papers are contained in this KMS focus section:

- Heat Treatments to Develop High-Strength Ferritic Ductile Iron, R. Gundlach

- Searching for Graphite Nodule Nuclei Using Automated SEM/EDX Analysis, S. Lekakh

- From Individual Graphite Assignment to an Improved Digital Image Analysis of Ductile Iron, J. Friess, U. Sonntag, I. Steller, A. BührigPolaczek

- Modification of Silicon Microsegregation in Solid-Solution-Strengthened Ductile Iron by Alloying with Aluminum, D. Franzen, P. Weiß, B. Pustal, A. Bührig-Polaczek

- Why Is Graphite Spherical in Ductile Iron? A Study of Elemental Distributions at Interfaces in Ductile Iron Using Atom Probe Tomography and Transmission Electron Microscopy, J. Qing, M. Xu, V. Pikhovich

- Inoculation Solutions Against Metallurgical Problems, A. Fay, P. Pinel

- Demystifying Shrinkage Porosity in Ductile Iron Castings, A. Alagarsamy, S. Kumar

- Influence of Carbide-Promoting Elements on the Microstructure of High-Silicon Ductile Iron, M. Riebisch, B. Pustal, A. Bührig-Polaczek

- Graphite Nucleation in Compacted Graphite Cast Iron, G. Alonso, D. Stefanescu, P. Larrañaga, R. Suarez

- Solidification, Macrostructure and Shrinkage Formation of Ductile and Compacted Irons, R. Boeri, M. López, N. Tenaglia, J. Massone

- Microstructural Adjustment of the Degenerated Graphite Layer in Ductile Iron for Targeted Evaluation on the Fatigue Properties, A. Kutz, P. Martin, A. Bührig-Polaczek 
- Research on Solution Strengthened Ferritic Ductile Iron (SSFDI) Structure and Properties Using Different Treatment and Inoculation Materials, C. Hartung, R. Logan, A. Plowman, et al.
Publisher's Note Springer Nature remains neutral with regard to jurisdictional claims in published maps and institutional affiliations. 